\title{
COMPARISON OF ORAL ERYTHROMYCIN FORMULATIONS \\ IN THE HORSE USING PHARMACOKINETIC PROFILES
}

\author{
By \\ PATRICIA J. EWING \\ Doctor of Veterinary Medicine \\ Oklahoma State University \\ Stillwater, Oklahoma \\ 1988
}
Submitted to the Faculty of the
Graduate College of the Oklahoma State University in partial fulfillment of the requirements for the Degree of
MASTER OF SCIENCE
May, 1992




$$
\begin{aligned}
& \text { Thesio } \\
& 1040 \\
& 6.50
\end{aligned}
$$




\section{COMPARISON OF ORAL ERYTHROMYCIN FORMULATIONS}

IN THE HORSE USING PHARMACOKINETIC PROFILES

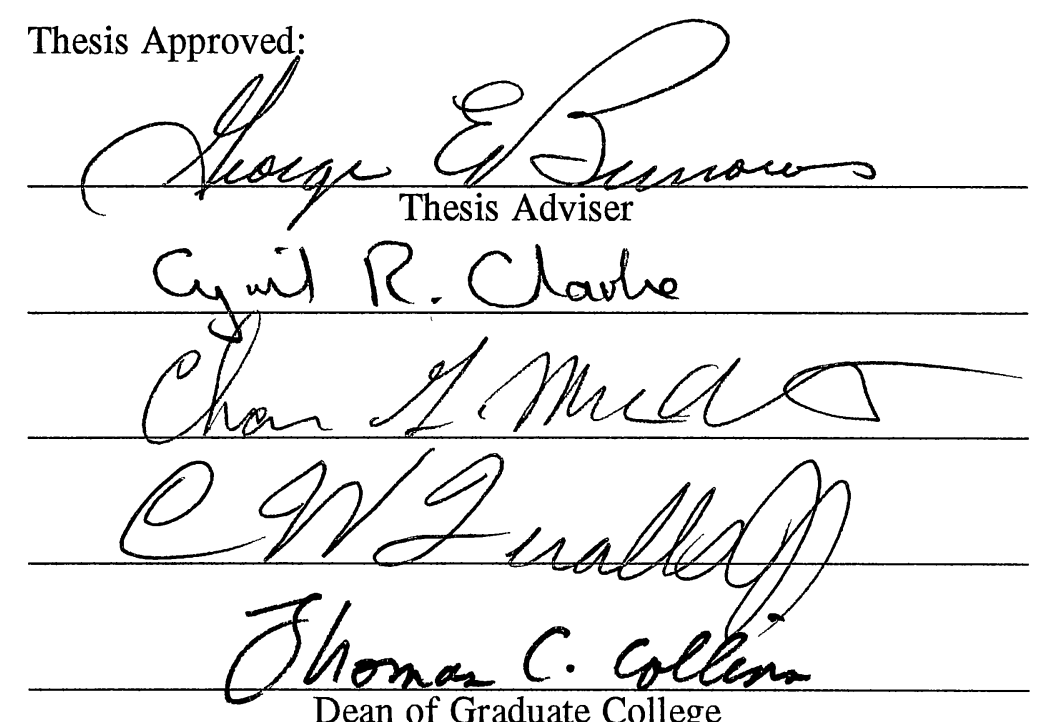

Dean of Graduate College 


\section{ACKNOWLEDGMENTS}

I wish to thank Dr. George Burrows for his guidance and support throughout my veterinary and graduate education. I sincerely appreciate his allowing me the flexibility of pursuing my residency in pathology while continuing my graduate work. I further appreciate his advising and recommending me for scholarships.

I wish to thank Drs. Cyril Clarke, George Burrows, Charles MacAllister and Chuck Qualls for their prompt review and critique of my thesis. I have learned a great deal from their suggestions.

To Dr. Myron Brown and Sanofi Animal Health of Overland Park, Kansas, I extend thanks for supplying formulations of erythromycin used in the study. I also wish to express my appreciation to the College of Veterinary Medicine and the Oklahoma Agriculture Experiment Station for their support.

I wish to thank the Oklahoma State University Foundation and the late Corey C. Lewis for scholarship support.

I extend thanks to Sherl Holesko for advise on formatting my thesis and for preparing the tables. I also wish to thank Dr. Greg Campbell for helping with the figures. To Dr. Bruce Lessley, I extend appreciation for his help with statistical procedures and for moral support.

I extend special thanks to Dr. Roger Panciera for prodding me along to finish writing my thesis. But more importantly, I thank Dr. Panciera for his educational guidance in both veterinary school and my pathology residency. The problem solving approach he taught me will be used for a lifetime. 


\section{TABLE OF CONTENTS}

Page

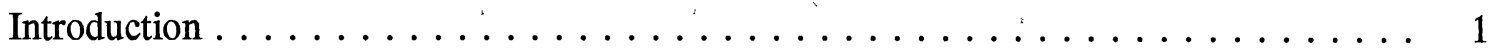

Material \& Methods . . . . . . . . . . . . . . . . . . . . . . . 2

Animals. ......................... 2

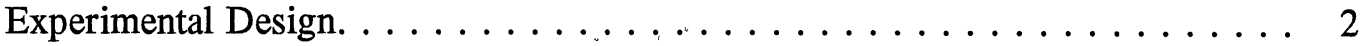

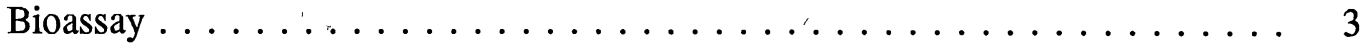

Pharmacokinetic Analysis . . . . . . . . . . . . . . . . 4

Statistical Analysis. . . . . . . . . . . . . . . . . . . 4

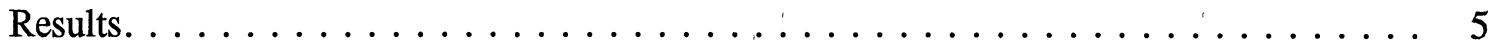

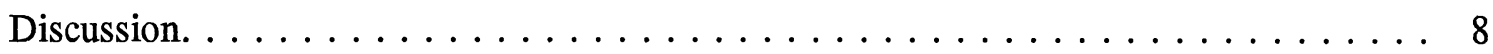

References .............................. 15 


\section{LIST OF TABLES}

Table

Page

I. Pharmacokinetic Parameters' (Means \pm SD) of Erythromycin Preparations After Oral Administration of a Single Dose, Either $25 \mathrm{mg} / \mathrm{kg}$ or $37.5 \mathrm{mg} / \mathrm{kg}$. . .

II. Pharmacokinetic Parameters (Means \pm SD) of Erythromycin Preparations After Administration of Multiple Doses, Either $25 \mathrm{mg} / \mathrm{kg}$ or $37.5 \mathrm{mg} / \mathrm{kg}$. . . . . .

III. Comparison of Estimated $\mathrm{AUC}_{(24-48 \mathrm{~h})}{ }^{\text {a }}$ for $25 \mathrm{mg} / \mathrm{kg} \mathrm{q} 8 \mathrm{~h}$ and $37.5 \mathrm{mg} / \mathrm{kg}$ $\mathrm{q} 12 \mathrm{~h}$ Doses of Erythromycin Phosphate and Estolate (Values are Means

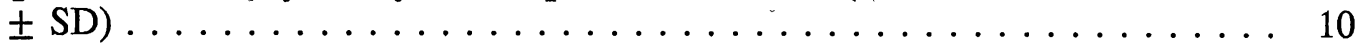

IV. Comparison of Peak and Trough Plasma Concentrations for $25 \mathrm{mg} / \mathrm{kg}$ and $37.5 \mathrm{mg} / \mathrm{kg}$ Doses of Erythromycin Phosphate and Estolate . . . . . . . . . . 10

V. Comparison of $\mathrm{T}_{(\mathrm{C}>\mathrm{MC})}{ }^{\mathrm{a}}$ for $25 \mathrm{mg} / \mathrm{kg}$ and $37.5 \mathrm{mg} / \mathrm{kg}$ Multiple Doses of Erythromycin Phosphate and Estolate (Values are Means \pm SD) . . . . . . . 11

\section{LIST OF FIGURES}

Figure

1. Plasma Concentration-Time Curves for Multiple Doses of Erythromycin Formulations (Each Curve is Presented as the Median \pm Median Deviation of 6 Horses). 


\section{Introduction}

Rhodococcus equi is a facultative intracellular bacterial pathogen that causes chronic pyogranulomatous bronchopneumonia in foals, particularly those between two to four months of age. Erythromycin in combination with rifampin is effective in vitro and in vivo for the treatment of Rhodococcus equi pneumonia (Prescott \& Nicholson, 1984; Sweeney et al., 1987). Using this antibiotic combination, Hillidge achieved an $88 \%$ success rate in treating 57 foals with Rhodococcus equi pneumonia (Hillidge, 1987). Erythromycin has several desirable properties which favor its clinical use in the treatment of this disease. First, it is widely distributed throughout peripheral tissues and achieves high concentrations in lung and bronchial secretions (Chow, 1984). Second, erythromycin is highly lipid soluble and concentrates within neutrophils (Prokesch \& Hand, 1982). Third, it can be administered orally to foals for prolonged periods with relatively few side effects (Hillidge, 1987).

Erythromycin base is composed of a macrocyclic lactone ring with two attached sugar moieties. This highly lipid soluble antibiotic, which is a weak base with a $\mathrm{pK}_{\mathrm{a}}$ of 8.8 , is rapidly inactivated in the acidic environment of the stomach (Chow, 1984). To prevent inactivation, protective enteric coatings and chemical modifications including formation of esters or salts from the base have been implemented. Several oral formulations, including erythromycin estolate, ethylsuccinate and stearate, are commercially available for use in humans (Fraser, 1980). Erythromycin estolate (the lauryl sulfate salt of the propionyl ester) and erythromycin ethylsuccinate are absorbed as inactive esters from the duodenum and require subsequent hydrolysis to the active free base. In contrast, the stearate salt dissociates in the duodenum and is absorbed as the free base (Chow, 1984). Erythromycin phosphate, another salt preparation, is added to drinking water for use as an antibacterial agent in chickens and turkeys. 
Pharmacokinetic data on erythromycin administered orally to horses is limited. Based on pharmacokinetic studies in horses using erythromycin estolate, Prescott, et al. recommended giving the drug four times daily at a dose of $25 \mathrm{mg} / \mathrm{kg}$. However, treatment of Rhodococcus equi pneumonia usually extends for 4 to 8 weeks, and because young foals can be difficult to restrain and medicate, a dosage interval of 6 hours might decrease owner compliance. Therefore, a 12 hour dosage interval might be better accepted. In addition, because of the cost in using erythromycin for four to eight weeks, it would be desirable to use a relatively inexpensive formulation.

The objectives of the experiments were threefold: (1) various erythromycin formulations were compared to determine if the less expensive salt formulations, erythromycin phosphate or erythromycin stearate, could be substituted for the more expensive esters, erythromycin estolate and erythromycin ethylsuccinate, in the treatment of Rhodococcus equi pneumonia; (2) erythromycin estolate and erythromycin phosphate were compared at two dosage intervals to assess the feasibility of using a longer dosage interval than 6 hours; and (3), since significant dose to dose variation in plasma concentration is reported in humans given oral erythromycin (Colburn et al., 1977), pharmacokinetic parameters after single dose and after multiple dose administration were compared.

\section{Materials and Methods}

\section{ANIMALS}

Six Quarter Horses ( 3 mares, 2 geldings, and 1 stallion) aged 1 to 16 years and weighing 277 to $477 \mathrm{~kg}$ were used. The horses were maintained on prairie grass hay, an oats, sweet feed and bran mixture and given water ad lib.

\section{EXPERIMENTAL DESIGN}

The six horses were subjected to six treatments with erythromycin of different formulation or dosage using a 6 × 6 Latin square design. Formulations of erythromycin and dos- 
ages used were: estolate, $25 \mathrm{mg} / \mathrm{kg}$ given every 8 hours (q8h) for four doses; estolate, 37.5 $\mathrm{mg} / \mathrm{kg}$ given every 12 hours (q12h) for 3 doses; ethylsuccinate, $25 \mathrm{mg} / \mathrm{kg}$ given $\mathrm{q} 8 \mathrm{~h}$ for 4 doses; stearate, $25 \mathrm{mg} / \mathrm{kg}$ given $\mathrm{q} 8 \mathrm{~h}$ for 4 doses; phosphate, $25 \mathrm{mg} / \mathrm{kg}$ given $\mathrm{q} 8 \mathrm{~h}$ for 4 doses; and phosphate, $37.5 \mathrm{mg} / \mathrm{kg}$ given $\mathrm{q} 12 \mathrm{~h}$ for 3 doses. Horses were not fasted prior to administration of treatments. Each animal was given the six treatments in a different order, thereby minimizing the effects of sequence on the results. An interval of two weeks was allowed between treatments. Erythromycin ethylsuccinate and erythromycin stearate tablets were crushed to powder consistency. Erythromycin estolate capsules were opened and the powder collected. Erythromycin phosphate is commercially available in powder form; therefore, it did not require processing. Next, all formulations were mixed with corn syrup, placed in a $60 \mathrm{cc}$ plastic syringe with the needle hub removed and administered orally. Blood samples were collected in glass tubes containing sodium heparin before and 60, 90, 120, 180, 240, 300, 360,480 minutes after administration of the first dose and again after either the third dose for $37.5 \mathrm{mg} / \mathrm{kg}$ treatments or the fourth dose for $25 \mathrm{mg} / \mathrm{kg}$ treatments. The blood samples were refrigerated, centrifuged, and the plasma was collected the same day. Plasma samples were stored at $-30^{\circ} \mathrm{C}$ until assayed.

\section{BIOASSAY}

The plasma samples were bioassayed by ân agar-gel diffusion method using Micrococcus luteus ATCC 9341 as the test organism with a level of detectability of approximately $0.1 \mu \mathrm{g} / \mathrm{ml}$ (Bennett et al., 1966). Standard solutions were prepared in horse plasma by appropriate serial dilutions of erythromycin base. All unknowns and standards were analyzed in duplicate and the unknown plasma samples were analyzed undiluted and diluted to one half with control plasma. Zone widths were measured and converted to plasma concentrations using standard curves for each 81-well agar plate. 


\section{PHARMACOKINETIC ANALYSIS}

Plasma concentrations were plotted against time on semilogarithmic coordinates and examined for fit to a 1- or 2-compartment model. Coefficients and exponents of the disposition curves that best described the changes in plasma erythromycin concentrations were calculated by iterative least squares non-linear regression analysis, using the ESTRIP computer program (Brown \& Manno, 1978). Area under the curve (AUC) was determined by the trapezoidal method and by using the calculated polyexponential equation to infinity. Time taken to achieve maximal plasma concentration following per os administration $\left(\mathrm{T}_{\max }\right)$ was calculated using differential calculus. Data were further analyzed using noncompartmental methods according to the statistical moment theory (Mayer \& Brazzell, 1988). The results are presented as means and standard deviations, except for pharmacokinetic parameters not normally distributed, which are presented as medians and median deviations.

\section{STATISTICAL ANALYSIS}

Statistical analysis to determine differences in area under the curve (AUC), maximal erythromycin plasma concentrations $\left(\mathrm{C}_{\max }\right), \mathrm{T}_{\max }$, half-life of elimination $\left(t_{1 / 2 \beta}\right)$ and mean residence time (MRT) among the various formulations were carried out using analysis of variance (Steele \& Torre, 1980). Because $t_{1 / 2 \beta}$ and MRT are not normally distributed, ranktransformation of data was performed prior to execution of analysis of variance (Conover \& Iman, 1981). Further testing of significant pairs was accomplished using the Tukey W test (Steele \& Torre, 1980). Additionally, statistical analyses were carried out to determine differences in AUC, $\mathrm{C}_{\max }, \mathrm{T}_{\max }, t_{1 / 2 \mathrm{~B}}$ and MRT between single dose and multiple dose administration for each formulation. Testing of significance was accomplished using the paired $t-$ test for $\mathrm{AUC}, \mathrm{C}_{\max }$ and $\mathrm{T}_{\max }$, and using the Wilcoxon test for $t_{1 / 2 \beta}$ and MRT. To assess differences between $37.5 \mathrm{mg} / \mathrm{kg}$ q12h and $25 \mathrm{mg} / \mathrm{kg}$ q8h doses for phosphate and estolate formulations, three comparisons were made. First, $\mathrm{AUC}_{(24-48 \mathrm{~h})}$ was estimated by multiplying the $\mathrm{AUC}_{(24-32 \mathrm{~h})}$ by three for $25 \mathrm{mg} / \mathrm{kg}$ q8h doses and by multiplying $\mathrm{AUC}_{(24-36 \mathrm{~h})}$ by two for 
$37.5 \mathrm{mg} / \mathrm{kg} \mathrm{q12h}$ doses. $\mathrm{AUC}_{(24-32 \mathrm{~h})}$ and $\mathrm{AUC}_{(24-36)}$ were determined from fitted curve data. In making this comparison, it is necessary to assume that AUC from dose to dose is similar. Testing of significance was accomplished using the paired t-test. Second, peak and trough plasma concentrations for $37.5 \mathrm{mg} / \mathrm{kg} \mathrm{q} 12 \mathrm{~h}$ and $25 \mathrm{mg} / \mathrm{kg}$ q8h doses were compared using the paired t-test. Third, for multiple doses of erythromycin estolate and phosphate, mean durations of plasma concentrations above the reported minimal inhibitory concentration $\left(\mathrm{T}_{\mathrm{C}>\mathrm{MIC}}\right)$ of $0.25 \mu \mathrm{g} / \mathrm{ml}$ for Rhodococcus equi (Prescott, 1981), were determined from fitted curve data and compared using the paired t-test. Differences were declared significant at $\mathrm{p} \leq 0.05$.

\section{Results'}

Using nonlinear regression analysis, it was found that plasma erythromycin concentrations were best described by a biexponential expression: $\mathrm{C}_{\mathrm{p}}=\mathrm{De}^{-\delta \mathrm{t}}+\mathrm{Be}^{-\mathrm{Bt}}$, where $\mathrm{Cp}$ is the concentration of drug in the plasma at time t, D and B are intercept terms, and $\delta$ and $B$ are the hybrid rate constants related to absorption and elimination phases, respectively. Therefore, a 1-compartment absorption model was inferred to best describe erythromycin disposition.

The median plasma concentration-time curves for multiple doses of various erythromycin formulations are shown in Figure 1.' From these curves, it appears that greater plasma concentrations are attained for the salt formulations, particularly the phosphate, than for the ester formulations, ethylsuccinate and estolate.

A comparison of pharmacokinetic parameters (means $\pm \mathrm{SD}$ or medians $\pm \mathrm{MD}$ ) of erythromycin formulations after oral administration of a single dose, either $37.5 \mathrm{mg} / \mathrm{kg}$ or 25 $\mathrm{mg} / \mathrm{kg}$, is shown in Table I. The AUC values for phosphate $(25 \mathrm{mg} / \mathrm{kg}$ and $37.5 \mathrm{mg} / \mathrm{kg}$ ) and stearate were significantly greater $(\mathrm{p} \leq 0.05)$ than for estolate $(25 \mathrm{mg} / \mathrm{kg}$ and $37.5 \mathrm{mg} / \mathrm{kg})$ and ethylsuccinate. There were no significant differences in $\mathrm{C}_{\max }, \mathrm{T}_{\max }, t_{1 / 2 \mathrm{~B}}$ or MRT among the erythromycin preparations.

Comparison of pharmacokinetic parameters (means \pm SD or medians \pm MD) of erythromycin formulations after oral administration of multiple doses $(25 \mathrm{mg} / \mathrm{kg}$ and 37.5 

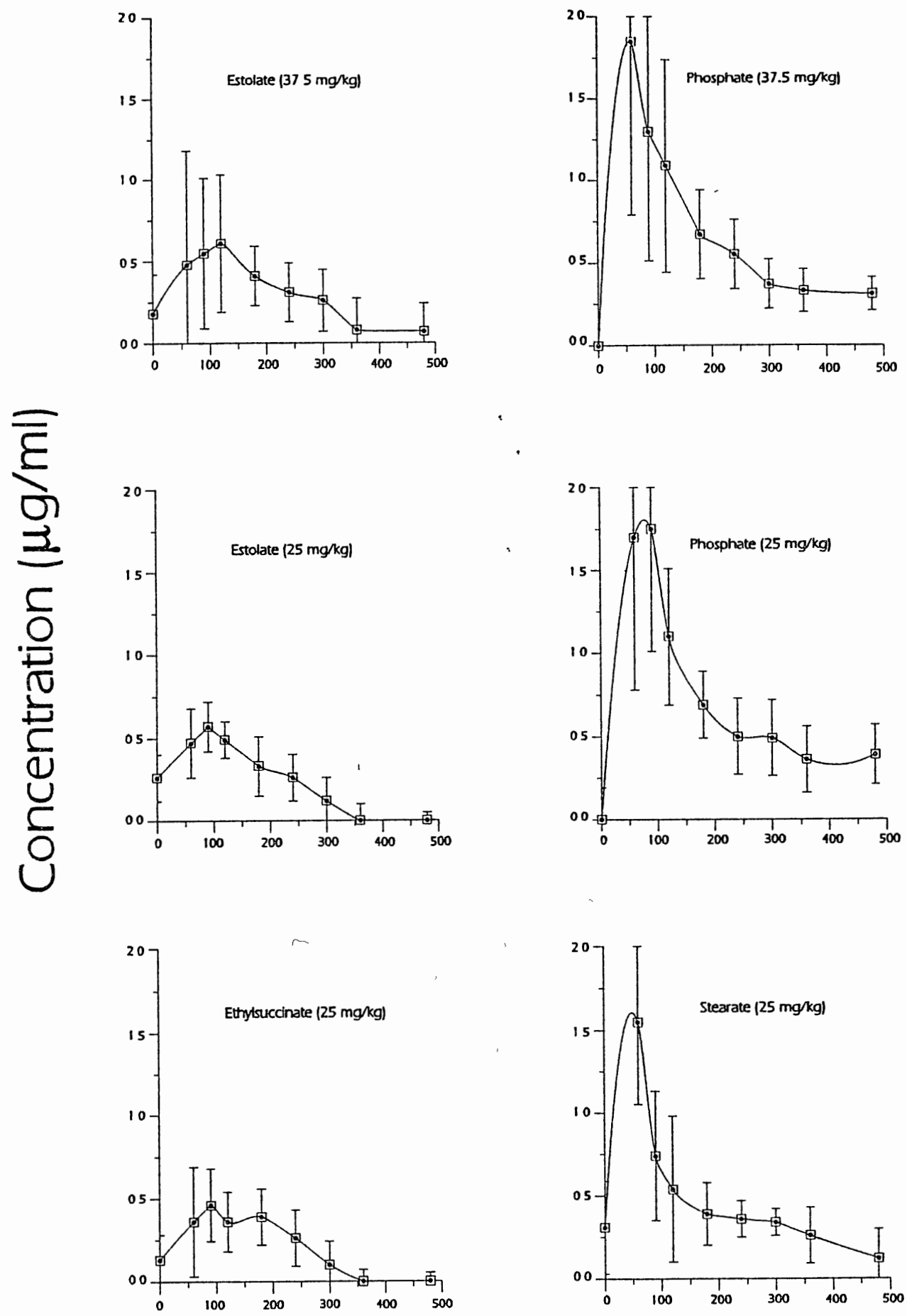

Time (minutes)

Figure 1. Plasma Concentration-Time Curves for Multiple Doses of Erythromycin Formulations (Each Curve is Presented as the Median \pm Median Deviation of 6 Horses) 
TABLE I

PHARMACOKINETIC PARAMETERS (MEANS \pm SD) OF ERYTHROMYCIN

PREPARATIONS AFTER ORAL ADMINISTRATION OF A SINGLE

DOSE, EITHER $25 \mathrm{mg} / \mathrm{kg}$ OR $37.5 \mathrm{mg} / \mathrm{kg}$

\begin{tabular}{|c|c|c|c|c|c|c|}
\hline \multirow[b]{2}{*}{ Parameter } & \multicolumn{2}{|c|}{ Phosphate } & \multicolumn{2}{|c|}{ Estolate } & \multirow{2}{*}{$\frac{\text { Stearate }}{25 \mathrm{mg} / \mathrm{kg}}$} & \multirow{2}{*}{$\frac{\text { Ethylsuccinate }}{25 \mathrm{mg} / \mathrm{kg}}$} \\
\hline & $25 \mathrm{mg} / \mathrm{kg}$ & $37.5 \mathrm{mg} / \mathrm{kg}$ & $25 \mathrm{mg} / \mathrm{kg}$ & $37.5 \mathrm{mg} / \mathrm{kg}$ & & \\
\hline $\mathrm{AUC}_{(0-8 \mathrm{~h})}(\mu \mathrm{g} \cdot \mathrm{min} / \mathrm{ml})$ & $220.7 \pm 107.9^{a}$ & $239.8 \pm 173.4^{\mathrm{a}}$ & $41.6 \pm 57.8^{b}$ & $105.6 \pm 78.9^{b}$ & $235.4 \pm 149.9^{\mathrm{a}}$ & $46.8 \pm 15.5^{b}$ \\
\hline $\mathrm{C}_{\max }(\mu \mathrm{g} / \mathrm{ml})$ & $0.5 \pm \quad 0.1$ & $0.6 \pm 0.2$ & $0.2 \pm$ & $0.3 \pm$ & $1.4 \pm 1.2$ & $0.2 \pm 0.1$ \\
\hline$t_{\max }(\min )$ & $132.2 \pm 54.3$ & $143.4 \pm 73.7$ & $122.2 \pm 40.5$ & $100.8 \pm$ & $79.8 \pm 28.7$ & $69.4 \pm 20.4$ \\
\hline$t_{1 / 2 B}^{*}(\min )$ & $293.6 \pm 184.6$ & $240.8 \pm 155.6$ & $93.5 \pm 189.2$ & $289.9 \pm 256.6$ & $130.7 \pm 176.0$ & $41.0 \pm 105.4$ \\
\hline $\mathrm{MRT}^{*}(\min )$ & $243.0 \pm 112.0$ & $224.0 \pm 83.0$ & $325.0 \pm 136.0$ & $297.0 \pm 98.0$ & $168.0 \pm 69.0$ & $121.0 \pm 101.0$ \\
\hline
\end{tabular}

Means within rows with the same superscript are not significantly different $(\mathrm{p} \leq 0.05)$.

Data analyzed using ANOVA followed by Tukey W.

${ }^{*} t_{1 / 2 \mathrm{~B}}$ and MRT were rank-transformed prior to analysis. Values are presented as median \pm median deviation $\left(\Sigma \mid \mathrm{x}_{1}-\right.$ median $\left.\mid / \mathrm{n}\right)$. 
$\mathrm{mg} / \mathrm{kg}$ ) is shown in Table II. Statistical differences in AUC values among formulations are similar to those following single dose administration except that the AUC of stearate (25 $\mathrm{mg} / \mathrm{kg}$ ) was not significantly different from the AUC of estolate $(37.5 \mathrm{mg} / \mathrm{kg})$. The $\mathrm{C}_{\max }$ of the phosphate $(37.5 \mathrm{mg} / \mathrm{kg})$ formulation was significantly greater $(\mathrm{p} \leq 0.05)$ than the $\mathrm{C}_{\max }$ of the estolate $(25 \mathrm{mg} / \mathrm{kg})$ formulation. There were no significant differences in $\mathrm{T}_{\max }, t_{1 / 2 \beta}$ or MRT among the erythromycin formulations.

Comparison of mean estimated $\mathrm{AUC}_{(24-48 \mathrm{~h})}$ for $37.5 \mathrm{mg} / \mathrm{kg} \mathrm{q} 12 \mathrm{~h}$ and $25 \mathrm{mg} / \mathrm{kg} \mathrm{q} 8 \mathrm{~h}$ doses of the phosphate and estolate formulations are presented in Table III. There were no significant differences in estimated $\mathrm{AUC}_{(24-48 \mathrm{~h})}$ between $37.5 \mathrm{mg} / \mathrm{kg} \mathrm{q} 12 \mathrm{~h}$ and $25 \mathrm{mg} / \mathrm{kg} \mathrm{q} 8 \mathrm{~h}$ doses.

Comparison of peak and trough plasma concentrations (means $\pm \mathrm{SD}$ ) of $37.5 \mathrm{mg} / \mathrm{kg}$ $\mathrm{q} 12 \mathrm{~h}$ versus $25 \mathrm{mg} / \mathrm{kg} \mathrm{q} 8 \mathrm{~h}$ doses of erythromycin estolate and phosphate are presented in Table IV. The trough plasma concentration following administration of a single $37.5 \mathrm{mg} / \mathrm{kg}$ dose of erythromycin estolate was significantly greater $(p \leq 0.05)$ than following administration of a single $25 \mathrm{mg} / \mathrm{kg}$ dose. No other statistical differences were present.

Comparison of $\mathrm{T}_{\mathrm{C}>\mathrm{MIC}}$ (means $\pm \mathrm{SD}$ ) among $37.5 \mathrm{mg} / \mathrm{kg} \mathrm{q} 12 \mathrm{~h}$ and $25 \mathrm{mg} / \mathrm{kg} \mathrm{q} 8 \mathrm{~h}$ doses of erythromycin phosphate and estolate are presented in Table V. No significant differences in $\mathrm{T}_{\mathrm{C}>\mathrm{MIC}}$ were present among $37.5 \mathrm{mg} / \mathrm{kg} \mathrm{q} 12 \mathrm{~h}$ and $25 \mathrm{mg} / \mathrm{kg}$ q8h multiple doses.

Comparison of parameters between single dose and multiple dose administration for each drug yielded the following results. The AUC and $\mathrm{C}_{\max }$ after the fourth $25 \mathrm{mg} / \mathrm{kg}$ dose of erythromycin phosphate were significantly greater $(\mathrm{p} \leq 0.05)$ than after administration of the first dose. Also, $\mathrm{C}_{\max }$ was significantly greater $(\mathrm{p} \leq 0.05)$ after administration of the third $37.5 \mathrm{mg} / \mathrm{kg}$ dose of erythromycin phosphate than after administration of the first dose. No significant differences were present among the other formulations.

\section{Discussion}

The results of this study indicate that the total amount of antibiotic present in plasma 
TABLE II

PHARMACOKINETIC PARAMETERS (MEANS \pm SD) OF ERYTHROMYCIN

PREPARATIONS AFTER ORAL ADMINISTRATION OF MULTIPLE

DOSES, EITHER $25 \mathrm{mg} / \mathrm{kg}$ OR $37.5 \mathrm{mg} / \mathrm{kg}$

\begin{tabular}{|c|c|c|c|c|c|c|}
\hline \multirow[b]{2}{*}{ Parameter } & \multicolumn{2}{|c|}{ Phosphate } & \multicolumn{2}{|c|}{ Estolate } & \multirow{2}{*}{$\frac{\text { Stearate }}{25 \mathrm{mg} / \mathrm{kg}}$} & \multirow{2}{*}{$\frac{\text { Ethylsuccinate }}{25 \mathrm{mg} / \mathrm{kg}}$} \\
\hline & $25 \mathrm{mg} / \mathrm{kg}$ & $37.5 \mathrm{mg} / \mathrm{kg}$ & $25 \mathrm{mg} / \mathrm{kg}$ & $37.5 \mathrm{mg} / \mathrm{kg}$ & & \\
\hline $\operatorname{AUC}_{(24-32 \mathrm{~h})}(\mu \mathrm{g} \cdot \mathrm{min} / \mathrm{ml})$ & $325.1 \pm 154.7^{a}$ & $259.2 \pm 163.2^{\mathrm{a}}$ & $99.7 \pm 48.5^{b}$ & $199.7 \pm 175.3^{\mathrm{a}, \mathrm{b}}$ & $223.5 \pm 102.8^{\mathrm{a}, \mathrm{b}}$ & $98.6 \pm 63.5^{b}$ \\
\hline $\mathrm{C}_{\max }(\mu \mathrm{g} / \mathrm{ml})$ & $0.7 \pm 0.4^{\mathrm{c}, \mathrm{d}}$ & d $1.0 \pm$ & $0.4 \pm$ & $0.8 \pm$ & $0.9 \pm 0.5^{\mathrm{c}, \mathrm{d}}$ & $0.4 \pm \quad 0.2^{\mathrm{c}, \mathrm{d}}$ \\
\hline $\mathrm{T}_{\max }(\min )$ & $128.5 \pm 60.1$ & $90.7 \pm 20.8$ & $89.8 \pm 14.7$ & $86.5 \pm 32.6$ & $77.6 \pm 33.4$ & $96.6 \pm 22.5$ \\
\hline$t_{1 / 2 B}^{*}(\min )$ & $228.5 \pm 112.5$ & $178.5 \pm 71.1$ & $296.8 \pm 122.3$ & $185.9 \pm 50.4$ & $148.6 \pm 81.9$ & $313.7 \pm 184.4$ \\
\hline $\mathrm{MRT}^{*}(\min )$ & $235.0 \pm 58.0$ & $235.0 \pm 44.0$ & $142.0 \pm 56.0$ & $175.0 \pm 41.0$ & $161.0 \pm 68.0$ & $141.0 \pm 62.0$ \\
\hline
\end{tabular}

Means within rows with the same superscript are not significantly different $(p \leq 0.05)$.

Data analyzed using analysis of variance followed by Tukey W.

${ }^{*} t_{1 / 2 \mathrm{~B}}$ and MRT were rank-transformed prior to analysis. Values are presented as median \pm median deviation $\left(\Sigma \mid \mathrm{x}_{1}-\right.$ median $\left.\mid / \mathrm{n}\right)$. 
TABLE III

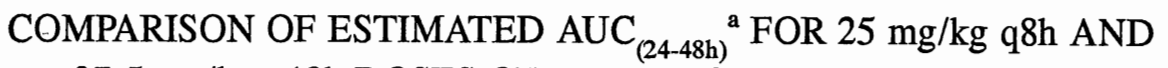
$37.5 \mathrm{mg} / \mathrm{kg}$ q12h DOSES OF ERYTHROMYCIN PHOSPHATE AND ESTOLATE (VALUES ARE MEANS \pm SD)

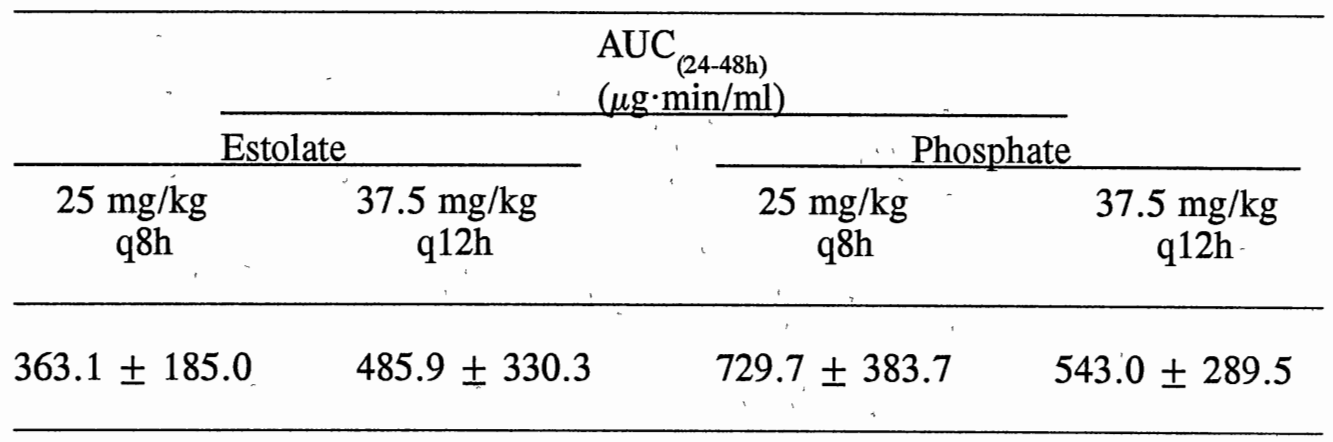

${ }^{a} \mathrm{AUC}_{(24-48 \mathrm{~h})}$ was estimated by multiplying $\mathrm{AUC}_{(24-32 \mathrm{~h})}$ by 3 for $\mathrm{q} 8 \mathrm{~h}$ doses and $\mathrm{AUC}_{(24-36 \mathrm{~h})}$ by 2 for $\mathrm{q} 12 \mathrm{~h}$ doses.

Data analyzed using paired t-test $(\mathrm{p} \leq 0.05)$.

TABLE IV

COMPARISON OF PEAK AND TROUGH PLASMA CONCENTRATIONS FOR $25 \mathrm{mg} / \mathrm{kg}$ AND $37.5 \mathrm{mg} / \mathrm{kg}$ DOSES OF ERYTHROMYCIN

PHOSPHATE AND ESTOLATE

\begin{tabular}{|c|c|c|c|c|c|}
\hline \multirow[b]{3}{*}{ Dose } & \multirow[b]{3}{*}{ Parameter } & \multicolumn{4}{|c|}{ Plasma Concentrations (mean $\mu \mathrm{g} / \mathrm{ml}+\mathrm{SD}$ ) } \\
\hline & & \multicolumn{2}{|c|}{ Estolate } & \multicolumn{2}{|c|}{ Phosphate } \\
\hline & & $\begin{array}{c}25 \mathrm{mg} / \mathrm{kg} \\
\mathrm{q} 8 \mathrm{~h}\end{array}$ & $\begin{array}{c}37.5 \mathrm{mg} / \mathrm{kg} \\
\mathrm{q} 12 \mathrm{~h}\end{array}$ & $25 \mathrm{mg} / \mathrm{kg}$ & $\begin{array}{c}37.5 \mathrm{mg} / \mathrm{kg} \\
\mathrm{q} 12 \mathrm{~h}\end{array}$ \\
\hline \multirow[t]{2}{*}{ Single } & Peak & $0.2 \pm 0.2$ & $0.6 \pm 0.4$ & $1.4 \pm 1.3$ & $1.6 \pm 1.6$ \\
\hline & Trough & $0.1 \pm 0.0 *$ & $0.3 \pm 0.1^{*}$ & $0.3 \pm 0.1$ & $0.4 \pm 0.1$ \\
\hline \multirow[t]{2}{*}{ Multiple } & Peak & $0.7 \pm 0.3$ & $1.2 \pm 1.0$ & $1.9 \pm 0.9$ & $1.6 \pm 1.0$ \\
\hline & Trough & $0.2 \pm 0.2$ & $0.3 \pm 0.2$ & $0.4 \pm 0.2$ & $0.4 \pm 0.2$ \\
\hline
\end{tabular}

*Paired t-test values are significantly different $(\mathrm{p} \leq 0.05)$. 
for esters and salts are not clear.' However, several unique aspects of equine herbivore gastrointestinal physiology may contribute to the variation. First, a horse's gastric pH has been shown to vary considerably with diet, feeding regimen and time relative to feeding (Argenzio, 1974). In horses fasted for 12 hours, gastric $\mathrm{pH}$ is relatively low (pH 2.1-2.4) (Sangiah, 1988) while, in non-fasted horses, gastric $\mathrm{pH}$ averages $4.5-6.0$ and may be as high as 6.8 (Argenzio, 1974; Baggot, 1977). Normally, èrythromycin base, erythromycin stearate and erythromycin phosphate are inactivated in gastric $\mathrm{pH}<4.0$, such as that of humans (Boggiano \& Gleeson, 1976). Assuming that the gastric pH of the horses in this study is similar to gastric $\mathrm{pH}$ reported for non-fasted horses, then the erythromycin salt formulations were unlikely to be inactivated in the more neutral environment of the equine stomach even through the enteric coating was destroyed in preparation of the corn syrup-drug slurry. In addition, the higher $\mathrm{pH}$ of the equine stomach would result in a greater proportion of nonionized drug; therefore, a portion of the erythromycin may be absorbed from the stomach. This is in contrast to humans, in which gastric absorption is negligible.

Assuming that, as in humans, the equine duodenum is the major site of absorption for erythromycin, differences in small intestine $\mathrm{pH}$ relative to drug $\mathrm{pK}_{\mathrm{a}}$ may contribute to discrepancies in results with erythromycin estolate. In humans, who generally eat meals periodically, intermittent delivery of acidic gastric contents to the small intestine and subsequent secretion of high bicarbonate pancreatic juice $(\mathrm{pH} \mathrm{8.8)} \mathrm{and} \mathrm{bile,} \mathrm{result} \mathrm{in} \mathrm{wide} \mathrm{fluctua-}$ tions in duodenal pH, 5.4 to 7.8 (Davenport, 1977). In contrast, horses usually eat almost continuously and consequently have a more steady delivery of ingesta, with a higher $\mathrm{pH}$, to the small intestine: In addition, equine pancreatic juice is continuously secreted and has a low concentration of bicarbonate ion. The $\mathrm{pH}$ of equine small intestinal contents increases from 6.0 in the duodenum to 7.3 in the ileum (Argenzio, 1974). Because of these differences, we speculate that equine duodenal $\mathrm{pH}$ may be lower and less variable than human duodenal $\mathrm{pH}$ after ingestion of a meal. Erythromycin estolate has a lower $\mathrm{pK}_{\mathrm{a}}(6.9)$, than erythromycin base ( $\mathrm{pK}_{\mathrm{a}} 8.8$ ) and thus, more of the drug would be in the absorbable nonionized form in the 
environment of the human duodenum accounting in part for its greater bioavailability. This advantage would be minimized in the presumably more acidic environment of the equine duodenum.

Whether the presence of food influences the absorption of erythromycin in horses remains to be determined. Studies in humans have shown that absorption of erythromycin stearate is decreased in the presence of food, while the absorption of erythromycin estolate and ethylsuccinate is enhanced or unaffected by food (Fraser, 1980; Bechtol, 1979). Since under normal feeding conditions, the horse's stomach is likely never empty, we expect that erythromycin absorption will occur in the presence of food the majority of the time. Furthermore, in the nonfasted horses of this study, plasma erythromycin concentrations achieved using the salt preparations were well above the reported minimal inhibitory concentration (MIC) of $0.25 \mu \mathrm{g} / \mathrm{ml}$ for Rhodococcus equi (Prescott, 1981). Therefore, even in the presence of food, erythromycin stearate and phosphate used at the doses in this study achieve appropriate plasma antibiotic concentrations.

The results of peak-trough plasma concentrations, $\mathrm{T}_{\mathrm{C}>\mathrm{MIC}}$ and estimated $\mathrm{AUC}_{(24-48 \mathrm{~h})}$ comparisons indicate that differences between $37.5 \mathrm{mg} / \mathrm{kg}$ q12h and $25 \mathrm{mg} / \mathrm{kg} \mathrm{q} 8 \mathrm{~h}$ dosage intervals for the two formulations studied are minimal. The only mean trough plasma concentrations below $0.25 \mu \mathrm{g} / \mathrm{ml}$ occurred with administration of a single dose of erythromycin estolate $25 \mathrm{mg} / \mathrm{kg}$ q8h. In antimicrobial therapy, peak plasma antibiotic concentrations should exceed the MIC for the pathogen, but the length of time these concentrations must be maintained is difficult to determine (Koritz, 1984). Since erythromycin achieves significantly greater concentrations in tissue such as lung than in plasma, the slightly lower plasma antibiotic concentration with erythromycin estolate may still be reasonable (Chow, 1984).

Human oral erythromycin studies have demonstrated that single dose plasma levels poorly predict those obtained following multiple doses, with observed AUC and $\mathrm{C}_{\max }$ exceeding those predicted from single dose data (Welling et al., 1979; Croteau et al.,, 1988; Colburn et al., 1977). Likewise, in the present study, we demonstrated similar differences 
between single and multiple doses of erythromycin phosphate. A 1-compartment absorption model appeared to be adequate to describe the erythromycin disposition in our study. However, discrepancies exist in the human literature concerning the most appropriate model to describe the unusual dose-to-dose variability in oral erythromycin pharmacokinetics. Colburn et al. concluded that a 1-compartment model assuming zero-order absorption was most appropriate, while Welling et al. provided evidence that a first-order absorption model following multiple doses was more appropriate. It is uncertain which model best describes oral erythromycin pharmacokinetics in horses. Therefore, investigators designing future experiments using erythromycin phosphate should take into account potential dose-to-dose variability in absorption parameters.

In conclusion, our results indicate that erythromycin salt formulations can be substituted for erythromycin estolate in the treatment of Rhodococcus equi pneumonia. Furthermore, erythromycin estolate and erythromycin phosphate administered at doses of $37.5 \mathrm{mg} / \mathrm{kg}$ q12h maintain plasma concentrations above the MIC for Rhodococcus equi for most of the dosage interval. Finally, future studies using oral erythromycin phosphate should consider that single dose parameters may not necessarily predict disposition following multiple doses. The effects of age and combination with rifampin on oral erythromycin pharmacokinetics remains to be determined. 


\section{REFERENCES}

Argenzio, R.A., Southworth, M., \& Stevens, C.E. (1974) Sites of organic acid production and absorption in the equine gastrointestinal tract. American Journal of Physiology, 5, 1043-1050.

Baggot, J.D. (1977) The absorption of drugs; bioavailability. In Principles of Drug Disposition in Domestic Animals: The Basis of Veterinary Clinical Pharmacology. pp. 22-47 W.B. Saunders Co., Philadelphia.

Bennett, J.V., Brodie, J.L., Benner, E.J. \& Kirby, W.M. (1966) Simplified, accurate method for antibiotic assay of clinical specimens. Applied Microbiology, 14, 170-177.

Boggiano, B.G., Gleeson, M. (1976) Gastric acid inactivation of erythromycin stearate in solid dosage forms. Journal of Pharmaceutical Sciences, 65, 497-502.

Bechtol, L.D., Stephens, V.C., Pugh, C.T., Perkal, M.B. \& Coretta, M.D. (1976) Erythromycin salts - comparative in-vivo hydrolysis and bioavailability. Current Therapeutic Research, 20, 610-622.

Bechtol, L.D., Bessent, C.T. \& Perkal, M.B. (1979) The influence of food on the absorption of erythromycin esters and enteric-coated erythromycin in single-dose studies. Current Therapeutic Research, 25, 618-625.

Brown, R.D. \& Manno, J.E. (1978) ESTRIP, a BASIC computer program for obtaining initial polyexponential parameter estimates. Journal of Pharmaceutical Sciences, 67, $1687-1691$.

Chow, A.W. (1984) Erythromycin. In Antimicrobial Therapy. Eds. Ristuccia, A.M. \& Cunha, B.A. pp. 209-219. Raven Press, New York.

Colburn, W.A., DiSanto, A.R. \& Gibaldi, M. (1977) Pharmacokinetics of erythromycin on repetitive dosing. Journal of Clinical Pharmacology, 17, 592-600. 
Conover, W.J. \& Iman, R.L. (1981) Rank transformations as a bridge between parametric and nonparametric statistics. The American Statistician, 35, 124-130.

Croteau, D., Bergeron, M.G., LeBel (1988) Pharmacokinetic advantages of erythromycin estolate over ethylsuccinate as determined by high-pressure liquid chromatography. Antimicrobial Agents and Chemotherapy, 32, 561-565.

Davenport, H.W. (1977) Gastric digestion and emptying; absorption. In Physiology of the Digestive Tract. 4th Ed. pp. 187-197. Year Book Medical Publishers Inc., Chicago.

Fraser, D.G. (1980) Selection of an oral erythromycin product. American Journal of Hospital Pharmacology, 37, 1199-1205.

Hillidge, C.J. (1987) Use of erythromycin-rifampin combination in treatment of Rhodococcus equi pneumonia. Veterinary Microbiology, 14, 337-342.

Koritz, G.D. (1984) Relevance of peak and trough concentrations to antimicrobial drug therapy. Journal of the American Veterinary Medical Association, 185, 1072-1075.

Mayer, P.R. \& Brazzell R.K. (1988) Application of statistical moment theory to pharmacokinetics. The Journal of Clinical Pharmacology, 28, 481-483.

Prescott, J.F. (1981) The susceptibility of isolates of Corynebacterium equi to antimicrobial drugs. Journal of Veterinary Pharmacology and Therapeutics, 4, 27-31.

Prescott, J.F., Hoover, D.J. \& Dohoo, I.R. (1983) Pharmacokinetics of erythromycin in foals and in adult horses. Journal of Veterinary Pharmacology and Therapeutics, $\mathbf{6}$, $67-74$.

Prescott, J.F., Nicholson, V.M. (1984), The effects of combinations of selected antibiotics on the growth of Corynebacterium equi. Journal of Veterinary Pharmacology and Therapeutics, 7, 61-64.

Prokesch, R.C. \& Hand, W.L. (1982) Antibiotic entry into human polymorphonuclear leukocytes. Antimicrobial Therapy and Chemotherapy, 21, 373-380.

Sangiah, S., McAllister, C.C., Amouzadeh, H.R. (1988) Effects of cimetidine and ranitidine on basal gastric $\mathrm{pH}$, free and total acid contents in horses. Research in Veterinary 
Science, 45, 291-295.

Steele, R.G., Torrie, J.H. (1980) Principle and Procedures of Statistics. A Biomedical Approach. 2nd Ed. McGraw-Hill Book Co., New York.

Sweeney, C.R., Sweeney, R.W. \& Divers, T.J. (1987) Rhodococcus equi pneumonia in 48 foals: response to antimicrobial therapy. Veterinary Microbiology, 14, 329-336.

Welling, P.G., Elliott, R.L., Pitterle, M.E., Corrick-West, H.P. \& Lyons, L.L. (1979) Plasma levels following single and repeated doses of erythromycin estolate and erythromycin stearate. Journal of Pharmaceutical Sciences, 68, 150-155. 


\author{
VITA \\ Patricia J. Ewing \\ Candidate for the Degree of \\ Master of Science
}

\title{
Thesis: COMPARISON OF ORAL ERYTHROMYCIN FORMULATIONS IN THE HORSE USING PHARMACOKINETIC PROFILES
}

Major Field: Physiological Sciences

Biographical:

Personal Data: Born in Tulsa, Oklahoma, June 24, 1963, the daughter of Thomas N. and Joan L. Ewing

Education: Graduated from Memorial Senior High School, Tulsa, Oklahoma in May 1981; received Doctor of Veterinary Medicine Degree from Oklahoma State University in May, 1988; completed requirements for the Master of Science degree at Oklahoma State University in May 1992.

Professional Experience: Resident, Department of Veterinary Pathology, Oklahoma State University, September, 1989 to June, 1992. 